\title{
OMREŽJE OBČIN - POVEZANOST V ALPAH - PROJEKT, KI ŽIVI
}

\section{Trajnostno ohranjanje bogastva alpskega prostora - preizkusni kamen bodoče Evrope regij in priložnost za slovenske alpske občine}

\begin{abstract}
Neda Kovačič*
Izvleček

UDK 711:504.06(234.3)

$V$ prispevku so predstavljene osnovne značilnosti projekta »Omrežje občin - povezanost v Alpah«, ki je kot pilotni projekt potekal leta 1997. V projekt je bila vključena tudi občina Kranjska gora, ki je $v$ skladu z osnovnima vodiloma projekta, to je sonaravni razvoj in varovanja okolja $v$ Alpah, izdelala in delno realizirala tudi nekaj konkretnih projektov.
\end{abstract}

Ključne besede: projekt Omrě̌je občin - povezanost v Alpah, sonaravno trajnostni razvoj, Kranjska gora, Julijske Alpe, Slovenija.

NETWORKING IN THE EUROPEAN ALPS

\section{Abstract}

The article represents the basic elements of "Municipality network - connection in the Alps". It was a pilot project in 1997. Kranjska Gora was also included in the project according to the sustainable development and Alpine landscape protection guidelines. The results were some concrete projects.

Key words: Municipality network project - connections in the Alps, sustainable development, Kranjska Gora, Julian Alps, Slovenia

\footnotetext{
* Dipl.oec., Občina Kranjska gora, Kolodvorska 1a, 4280 Kranjska gora, Slovenija
} 


\section{ALPE KOT PREIZKUSNI KAMEN NOVE EVROPE REGIJ}

Alpski prostor ima poleg okoljskega in gospodarskega tudi izjemen kulturni pomen, s svojo bogato naravno in kulturno dediščino pa zaznamuje družbeni in kulturni razvoj prebivalstva. Za

trajnostno ohranjanje bogastva alpskega prostora so odgovorni njegovi prebivalci gre za trajnostno načrtovanje razvoja, za povezovanje in za skupno odgovornost Evrope, njenih regij, držav in občin.

\section{OMREŽJE OBČIN - POVEZANOST V ALPAH}

Projekt Omrežje občin - povezanost v Alpah je kot pilotni projekt potekal v letu 1997. Vanj je bilo vključenih 27 evropskih alpskih občin, iz Slovenije občini Kranjska Gora in Bovec. V pilotni fazi je vsaka občina izdelala Program sonaravnega okoljevarstvenega razvoja, ki temelji na temeljnih usmeritvah Alpske konvencije in njenih protokolov. Temeljno izhodišče je uvajanje okoljevarstvenih meril $\mathrm{v}$ trajnostno načrtovanje razvoja $\mathrm{v}$ občinah.

\section{PROJEKT, KI ŽIVI}

Občinam, ki sodelujejo v projektu, ne gre samo za lastno predstavitev (čeprav je večina turistično zelo razvitih občin), temveč želijo s skladnim načrtovanjem, izmenjavo izkušenj in avtonomijo pri odločanju vplivati na razvoj v alpskem prostoru. Pri tem tudi občina Kranjska Gora ni izjema, saj se občine v Alpah srečujejo s sorodnimi problemi. Nekatere so v prednosti, ker so jih že rešile in lahko dragocene izkušnje prenesejo na druge. Problemi urejanja prometa v turističnih središčih, uvajanje okolju prijaznih turističnih proizvodov, vplivanje na zakonodajo, ki ureja trženje kmetijskih proizvodov in dopolnilnih dejavnosti na visokogorskih kmetijah, ohranjanje kulturne krajine, ravnanje $\mathrm{z}$ odpadki, skrb za pitno vodo in učinkovita raba energije so prisotni v vseh alpskih občinah. 


\section{NAMEN IN CILJI PROJEKTA}

Kot članica projekta Omrežje občin - povezanost v Alpah se je občina s tem zavezala, da bo spoštovala in uresničevala temeljne usmeritve Alpske konvencije, ki zagotavlja varovanje naravnih in kulturnih vrednot ter okolju prijazen in družbeno sprejemljiv razvoj - trajnostni razvoj.

\section{NAMEN PROJEKTA}

Osnovni namen projekta je izdelati program sonaravnega razvoja in varovanja okolja v občini, ki bo omogočil :

- pridobiti certifikat okolju prijazne občine,

- izmenjavo izkušenj in znanja med občinami v alpskem prostoru, ki so vključene $\mathrm{v}$ projekt, povezovanje županov in strokovnih skupin ter skupno delo pri projektih,

- $\quad$ snovanje projektov, ki bodo imeli možnost kandidiranja za finančna sredstva iz mednarodnih ustanov.

\section{OBMOČJE VELJAVNOSTI PROGRAMA}

Program v prvi vrsti velja za izbrana delovna področja promet in turizem, $v$ celoti pa se nanaša na vsa druga delovna področja: kmetijstvo, ravnanje z odpadki, voda, energija, urejanje krajine, urejanje prostora, informiranje, gorski gozd ...

Projekt Omrežje občin - povezanost v Alpah je pilotni projekt, ki trenutno vključuje 27 izbranih občin iz Francije, Švice, Lihtenštajna, Nemčije, Avstrije, Italije in Slovenije. 


\section{OBČINE}

\begin{tabular}{|c|c|c|c|c|c|c|}
\hline AVSTRIJA & ITALIJA & NEMČIJA & ŠVICA & SLOVENIJA & FRANCIJA & LIHTENŠTAJN \\
\hline Brandberg & \begin{tabular}{|l} 
Bobbio \\
Pelice
\end{tabular} & \begin{tabular}{|l} 
Bad \\
Reichenhall
\end{tabular} & Saas Fee & Bovec & $\begin{array}{l}\text { Ste Marie } \\
\text { du Mont }\end{array}$ & Schaan \\
\hline Grossarming & Budoia & Grossweil & Salgesch & \begin{tabular}{|l} 
Kranjska \\
Gora
\end{tabular} & & \\
\hline Mäder & \begin{tabular}{|l|} 
Levico \\
Terme \\
\end{tabular} & Mittenwald & Silenen & & & \\
\hline $\begin{array}{l}\text { Saalbach- } \\
\text { Hinterglemm }\end{array}$ & $\begin{array}{l}\text { SanZeno di } \\
\text { Montagna } \\
\end{array}$ & $\begin{array}{l}\text { Oberammer- } \\
\text { gau }\end{array}$ & St.Martin & & & \\
\hline & \begin{tabular}{|l|} 
Treviso \\
Bresciano \\
\end{tabular} & Oberstaufen & \begin{tabular}{|l|} 
Val \\
Lumnezia \\
\end{tabular} & & & \\
\hline & Eppan & Schliersee & $\begin{array}{l}\text { Zweisimme } \\
\text { n }\end{array}$ & & & \\
\hline & Naturns & & & & & \\
\hline
\end{tabular}

Leta 1997 se je oblikovala baza podatkov in informativna predstavitev vseh občin in projektov, Združenje pa je dejavno tudi pri zbiranju pomoči za popotresno obnovo Bovca, pri pripravi na letno konferenco v Oberstaufnu in pri oblikovanju pogojev za vstop novih občin.

\section{TRAJNOSTNI RAZVOJ KOT TEMELJNI CILJ}

V Združenju alpskih občin so predstavniki občin in držav, župani, ki najbolje poznajo problematiko in vplivajo na načrtovanje na krajevni ravni. Skladno s tem si je občina Kranjska Gora zastavila tudi nekaj konkretnih projektov, ki jih uvaja oziroma so že v fazi izvedbe:

$\Rightarrow$ na področju turizma: projekt kulturnega turizma in povezava turističnih poti na območju tromeje Avstrija-Italija-Slovenija $\mathrm{z}$ imenom »Civis Occidentalisdržavljan Evrope« - projekt že teče;

$\Rightarrow$ pohodniška pot po tromeji: gozdna - turistična pohodna pot, ki poteka po območju treh držav - mejni prehod ima kategorijo planinsko-turističnega prehoda - v fazi projekta;

$\Rightarrow$ Gorsko kmetijstvo in turizem: ustanovitev Razvojne zadruge za trženje domačih proizvodov s kmetij - v izgradnji trgovina, sirarna in večnamenski prostor skupaj z ureditvijo vaškega jedra v vasi Dovje na vhodu v Triglavski 
narodni park - v okviru projektov CRPOV (Celostni razvoj podeželja in obnova vasi);

$\Rightarrow$ kolesarske steze: izdelan je zemljevid in turistični vodnik kolesarskih poti $\mathrm{v}$ občini Kranjska Gora - nosilec Zavod za promocijo in razvoj turizma občine Kranjska Gora;

$\Rightarrow$ projekt daljinske mednarodne kolesarske poti - priprava projektne dokumentacije za daljinsko kolesarsko povezavo od mejnega prehoda $v$ Ratečah po trasi opuščene železniške proge - v sodelovanju z Ministrstvom za promet in zveze, Direkcijo RS za ceste - projekt kandidira za sredstva iz programa PHARE CBC;

$\Rightarrow$ na področju varovanja narave in naravne dediščine: ureditev območja Naravnega rezervata Zelenci - informativne table, ureditev poti in razglednega stolpa - izvedba;

$\Rightarrow$ varovanje voda: izgradnja kanalizacijskega sistema v občini Kranjska Gora projekt je v prvi izvedbeni fazi in je hkrati največji ekološki projekt $\mathrm{v}$ občini ter podlaga za bodoči kvalitetni razvoj;

$\Rightarrow$ kulturna dediščina: obnova kozolcev - projekt »Kozolci - naša kulturna dediščina« - v fazi izvedbe - iz občinskih sredstev je bilo v 4 letih obnovljenih več kot 60 kozolcev, izdelana razstava, predstavitev projekta na mednarodnih konferencah, sodeluje Fakulteta za arhitekturo Univerze v Ljubljani;

$\Rightarrow$ promet: ureditev prometa $\mathrm{v}$ turističnih središčih in vaških jedrih in ureditev vaških jeder - $v$ fazi načrtovanja;

$\Rightarrow$ urejanje krajine: ureditev vaškega jedra v Podkorenu - arhitekturno zaščitena vas - izvedba;

$\Rightarrow$ informiranje : občina vsako leto izda Občinske informacije, občane tudi redno tedensko informira s pomočjo lokalnega radia in televizije.

Temeljni cilj Združenja Alpskih občin je avtonomija občin pri upravljanju z okoljem, določitev razvojnih ciljev in prednostnih nalog, ter izbira strokovnih ustanov, ki pomagajo pripeljati projekte do izvedbe. Pri tem je osnovno izhodišče TRAJNOSTNI RAZVOJ, ki upošteva vse razvojne sestavine, od okoljskih, gospodarskih, družbenih in kulturnih možnosti nekega območja. Podlaga za določanje razvojne strategije je KULTURNA KRAJINA s svojimi zmogljivostmi. Gospodarstvo (v Alpah predvsem turistična industrija) pozitivno in tudi negativno vpliva na okolje. Na eni strani gre za izrazita sezonska nihanja in $\mathrm{s}$ tem $\mathrm{v}$ zvezi $\mathrm{z}$ uvajanjem vedno novih proizvodov, ki naj bi zapolnili medsezone in enakomerneje porazdelili obremenitve. Gre za konične obremenitve, za prostorsko in sezonsko koncentracijo, ki se ji morata prilagajati promet in vsa ostala infrastruktura. Na drugi strani pa turizem tudi spodbuja uvajanje novih oblik turistične ponudbe, zlasti okolju sprejemljivejših oblik rekreacije (kolesarstvo, pohodništvo, kulturni turizem, sankanje, tek na smučeh ipd.), ter se na tržnih osnovah povezuje s kmetijstvom, 
predvsem dopolnilnimi dejavnostmi na kmetijah. Bistvo turističnega trženja kmetijskih pridelkov je kakovost in izvor izdelkov - blagovna znamka. Alpske občine podpirajo predvsem biološko kmetijstvo z blagovno znamko. Zavzemajo se tudi za podporo $\mathrm{v}$ Evropski uniji, kjer pa žal premalo pozornosti namenjajo temu segmentu in ukinjajo subvencije za gorsko kmetijstvo.

Tudi Slovenija se bo kot pridružena članica EU morala boriti za svoj alpski prostor in pogoje za ohranitev kmetijstva. Kmetijstvo v Alpah je predvsem ohranjevalec naravnega ravnotežja, urejevalec in »skrbnik" alpske pokrajine, ki je potencialni zbiralnik pitne vode za ravninska območja. Te usmeritve so v veliki meri upoštevane V protokolih Alpske konvencije »Gorsko kmetijstvo« ter »Varstvo tal«, ki sta usklajena tudi s slovenske strani, nista pa še ratificirana.

S tem postaja Omrežje alpskih občin vedno bolj pomemben partner evropskim, regionalnim in krajevnim ustanovam. Projekt je v Sloveniji pričela CIPRA International s sodelovanjem Triglavskega narodnega parka, finančno pa ga podpira tudi Ministrstvo za okolje in prostor.

Z vključitvijo v Omrežje Alpskih občin je občina Kranjska Gora pridobila predvsem dostop do informacij, možnost neposredne izmenjave izkušenj in sodelovanja na strokovnih seminarjih, konferencah in ekskurzijah, predvsem pa možnost nadaljevanja postopkov za pridobitev okoljskega certifikata. Tudi mednarodne konference, kot so Alpski forum v Garmisch-Partenkirchnu, letne konference Omrežja (Vals, Bovec, Oberstaufen), Alpski kulturni teden v Bovcu, mednarodna konferenca geografov »Melikovi geografski dnevi » pod naslovom Trajnostni razvoj v Alpah, razstave v Kranjski Gori in podobno, so dobra priložnost, da se tudi stroka vključi $v$ načrtovanje trajnostnega razvoja na vseh ravneh - na krajevni, regionalni in državni ravni. Predvsem na krajevni ravni nastajajo in se rešujejo problemi upravljanja s prostorom v skladu $\mathrm{z}$ načeli trajnosti.

Preko Omrežja se občina vključuje v mednarodne tokove in s tem v bodočo Evropo regij. Kot članica predsedstva Omrežja (župani iz vseh 7 držav) si občina Kranjska Gora predvsem prizadeva za pretok informacij, za vključitev novih občin, s predstavitvami svojih projektov in rešitev pa sodeluje na vseh mednarodnih konferencah Omrežja. Izkušnje so lahko zelo dobrodošle za druge občine, ki bi se želele vključiti, predvsem pa bi moral projekt Omrežje občin -povezanost v Alpah pridobiti finančno podporo države, vsaj za plačilo kotizacije, ki je določena glede na velikost občine ( od 100.000 do 400.000 Sit), ter za kritje stroškov koordinatorja, ki skrbi za uvajalno fazo programa. Trenutno so najresnejše kandidatke iz Slovenije občine Bled, Cerkno in Solčava.

Stroške »eko-audit teama« in udeležbe na konferencah krijejo občine same. Iz sredstev kotizacije Omrežje pokriva administrativne stroške, izdelavo domačih strani 
na internetu, organizacijo letne konference in strokovnih ekskurzij, v prihodnje pa bo Omrežje namenilo del sredstev za spodbujanje mladih raziskovalcev in diplomantov različnih strok in za raziskovalne naloge na področju Alp.

Glede na nacionalno strategijo slovenskega približevanja in vstopa v EU bi projekt Omrežje občin - povezanost v Alpah, lahko pomenil prvi korak k izvedbi Nacionalnega programa varstva okolja na krajevni ravni. Pri tem bi bila v veliko pomoč podpora in sodelovanje slovenskih raziskovalnih in strokovnih ustanov, ki se ukvarjajo z načrtovanjem trajnostnega razvoja, alpskim prostorom, turizmom ipd. Sodelovanje stroke pri izvajanju razvojnega koncepta $v$ občinah in regijah je odločilnega pomena za uspešnost projekta, zahteva pa jasen koncept in podporo vseh ravni odločanja v krajevni skupnosti - župana, občinskega sveta, strokovnih služb in javnosti.

\title{
NETWORKING IN THE EUROPEAN ALPS
}

\begin{abstract}
Summary
The communes of Kranjska gora and Bovec are active members of the Alpine Communal Network (ACN). A major goal of the participating communes is to exchange information on different levels and among different professions. Several conferences, meetings and excursions deal with the environment. The environmental certificate will be granted only to those communes, members of the ACN, who can prove that they are responsible regarding their natural and cultural heritage. Therefore the commune Kranjska gora was supportive of this geographic conference and has, recently, participated on several scientific meetings, like on the Alpenforum (Garmisch-Partenkirchen), the yearly gatherings of the ACN communes (Vals, Bovec, Oberstaufen) and elsewhere. Sustainable development on local, regional and state level was major topic of most of the conferences.

Through the institution of the Alpine Communal Network the commune of Kranjska gora tends to become a partner in the proclaimed, s. c. Europe of regions. It promotes the idea of networking among other partner-communes in Slovenia. Regarding the active role of both communes, Bovec and Kranjska gora, one would expect that the state of Slovenia would grant them the yearly ACN membership fee (up to 400.000) and actively support the post of the network coordinator. At the moment the communes of Bled, Cerkno and Solčava are seeking membership.
\end{abstract}


At present, the ACN funds are established to support the promotion of the member communes on Internet and to organize the yearly meeting and several excursions. In the future, part of the funds will be allocated to support young researchers, graduate and postgraduate students of different professions, who would, in their diploma works, contribute to the knowledge of the alpine environment and the Alps in general.

In support of the national strategy, of joining the European Union, the ACN member communes already follow European environmental protection guidelines. To strengthen the role of the national environmental protection program on the local level, the support of professional research fields, like geography, is appreciated. In particular professional evaluation of development programs will be sought. Sustainable development of tourism should be of major concern, of all: the scientists, mayors and local entrepreneurs. 